раструктуре всех хозяйствующих субъектов, включая малый и средний агробизнес.

Важной мерой является нефинансовая поддержка экспорта, которую могут оказывать региональные центры поддержки экспортноориентированных субъектов малого и среднего предпринимательства, включая оказание информационно-консультационных, промоутерско-организационных и прочих мер. Следует создать Центр поддержки экспорта Саратовской области, которые уже созданы в 11 субъектов Приволжского округа[2].

\section{СПИСОК ЛИТЕРАТУРЫ}

1. Заводило О.В. Формирование инновационных стратегий промышленных предприятий // Саратовской области - 80 лет: история, опыт развития, перспективы роста: сб. науч. тр. по итогам Междунар. науч.-практ. конф. в 3-х частях / Саратовский социально-экономический институт (филиал) РЭУ им. Г.В. Плеханова. - Саратов, 2016. - Режим доступа: seun.ru>...info...14/rubriki/63.3...istoria_rossii.php.
2. Портал внешнеэкономической информации. Режим доступа: http://www.ved.gov.ru/.

3. Приволжское таможенное управление. - Режим доступа: ptu.customs.ru.

4. Саратовская область в цифрах - 2016: краткий стат. сб. / Территориальный орган Федеральной службы государственной статистики по Саратовской области. - Саратов, 2017 - 256 с.

5. Саратовская область: опыт и стратегия развития / Н.П. Колядин [и др.]. - Саратов, 2004. - 406 с.

6. Суханова И.Ф., Лявина М.Ю. Формирование экспортного продовольственного потенциала России и ее регионов в условиях импортозамещения // Аграрный научный журнал. - 2017. - № 1. - С. 80-85.

Киреева Наталья Аркадьевна, д-р экон. наук, проф. кафедры «Маркетинг, экономика предприятий и организаизий», Саратовский социально-экономический институт (филиал) РЭУ им. Г.В Плеханова. Россия.

410003, г. Саратов, ул. Радищева, 89.

Тел.:89272271570.

Ключевые слова: агропромышленный комплекс; регион; экспорт; импорт продовольствия.

\title{
EXTERNAL ECONOMIC RELATIONS OF AIC INTHE SARATOV REGION IN THE CONDITIONS OF IMPORT SUBSTITUTION
}

Kireeva Natalya Arkadyevna, Doctor of Economic Sciences, Professor of the chair "Marketing, Economics of Enterprises and Organizations", Saratov Socio-Economic Institute (branch) of Federal Budgetary State Educational Institute of Higher Education. Russian Economic University named after G.V. Plekahnov. Russia. import.

Keywords: agro-industrial complex; region; export; food
The tendencies of development of foreign economic relations of the agro-industrial complex in the Saratov region are considered. The dynamics and structure of export and import of food products and agricultural raw materials are analyzed. It is concluded that, in general, the region is characterized by a tendency to reduce the import intensity of the agrarian sector, the growth of net food exports and the level of self-sufficiency in basic food products. The barriers controlling increase in food export volume are systematized, and measures for their elimination are formulated.

\section{КУЧЕРЕНКО Ольга Ивановна, Воронежский государственный аграрный университет имени uмnератора Петра I}

ПОПКОВА Елена Викторовна, Воронежский государственный аграрный университет имени uмnератора Петра I

Проведен анализ современного состояния мясного подкомплекса Центрально-Черноземного региона. Выявлены особенности его формирования, которые связаны с позитивными изменениями в процессе развития, обусловленные ускоренным ростом производства свинины и мяса птицы. Сделан вывод о том, что за исследуемый период наблюдается увеличение производства продукции в сельскохозяйственных организациях и снижение в хозяйствах населения. Определены прогнозные параметры развития мясного подкомплекса региона. Проведенные исследования позволили определить перспективные направления устойчивого развития мясного животноводства в ЦЧР: создание высокотехнологичных комплексов по убою животных, инновационных предприятий по мясопереработке, логистических компаний с разветвленной сетью дистрибъютерских иентров.

Введение. Мясной подкомплекс занимает ведущее место в продовольственном обеспечении Центрально-Черноземного региона (ЦЧР). В процессе его функционирования задействовано значительное количество основных про- изводственных фондов и трудовых ресурсов. Удельный вес в производстве валовой продукции региона составляет более $30 \%$. От эффективности развития подкомплекса зависит обеспечение населения мясом и мясопродуктами. 
Цель исследования - анализ современного состояния и выявление приоритетных направлений развития инновационно-ориентированного мясного подкомплекса региона.

методика исследований. В процессе исследования авторами использовались методы экономического анализа. Основным приемом является сравнение, заключающееся в сопоставлении изучаемых данных по годам, а также в разрезе областей ЦЧР. Применяемый способ относительных величин позволил выявить соотношения между исследуемыми показателями, а также определить долю региона в производстве мяса как в целом по РФ, так и в ЦФО.

Обоснование перспективных направлений развития мясного подкомплекса проведено на основе метода построения прогнозного сценария, предполагающего установление прогнозных параметров в зависимости от функционирования окружающей среды и различных вариантов его развития.

Информационной базой исследования послужили статистические данные по производству продукции животноводства в Российской Федерации и ЦЧР, а также Прогноз социально-экономического развития Российской Федерации на 2018 г. и на плановый период 2019 и 2020 гг.

Результаты исследований. Активная государственная поддержка способствовала положительным изменениям в мясном подкомлексе региона. Благодаря реализации Государственной программы, а также различных целевых программ на уровне региона наблюдается увеличение производства мяса всех видов скота и птицы в хозяйствах всех категорий ЦЧР в живой массе с 2239,3 в 2012 г. до 3165,7 тыс. т в 2016 г. (или на 41,4 \%). При этом в целом по Российской Федерации прирост составил 20,2\% (табл. 1). Наибольший рост зафиксирован в Курской и Тамбовской областях - соответственно в 2,8 и 1,8 раза.

Необходимо констатировать, что доля региона в производстве мяса в 2016 г. достигла $66,8 \%$ от ЦФО и 22,7 \% в целом от РФ.

Анализ динамики и структуры производс- тва мяса по видам в хозяйствах всех категорий региона показывает, что темп роста производства свиней на убой в живой массе за 20122016 гг. составил 1,7 раза, овец и коз 16,7 \%, птицы - 25,2 \%. Лидирующие позиции в мясном балансе региона занимают свинина $(48,5 \%)$ и птица $(44,6 \%)$ [4].

За исследуемый период наблюдается процесс увеличения производства скота и птицы на убой в сельскохозяйственных организациях с 85,5 \% в 2012 г. до 92,8 \% в 2016 г. При этом в хозяйствах населения происходил значительный спад производства. Данное обстоятельство обусловлено следующими причинами. Во-первых, распространение африканской чумы поставило под угрозу безопасность деятельности крупных промышленных комплексов, что привело к сокращению поголовья свиней мелкими товаропроизводителями [3]. Во-вторых, агрохолдинги, производящие мясную продукцию, обладают достаточными мощностями по производству комбикормов собственного производства. Это удешевляет себестоимость производимой продукции. При этом хозяйства населения используют покупные корма, что способствует удорожанию продукции. В-третьих, в последнее время наблюдается тенденция снижения закупочных цен на мясо и мясную продукцию, в результате чего мелкие товаропроизводители становятся неконкурентоспособными на рынке.

На основании проведенного исследования установлено, что Центрально-Черноземный регион обладает объективными условиями для дальнейшего роста производства скота и птицы, обусловленными благоприятными почвенными, метеорологическими, транспортными условиями, а также относительно меньшей капиталоемкостью производства и доставкой продукции в другие регионы.

В Прогнозе социально-экономического развития Российской Федерации на 2018 г. и на плановый период 2019 и 2020 гг. [6] заложены темпы роста производства сельскохозяйственной продукции в 2020 г. по отношению к уровню 2016 г. На основе этого были разработаны

Динамика объемов производства скота и птицы на убой в живой массе хозяйствами всех категорий, тыс. т $[7,8,9,10]$

\begin{tabular}{|l|c|c|c|c|c|}
\hline \multicolumn{1}{|c|}{ Административная единица } & 2012 г. & 2013 г. & 2014 г. & 2015 г. & 2016 г. \\
\hline Российская Федерация, всего & 11621,0 & 12222,9 & 12912,4 & 13475,4 & 13970,3 \\
\hline В том числе: ЦФО & 3470,8 & 3965,6 & 4138,4 & 4486,0 & 4737,4 \\
\hline из них ЦЧР & 2239,3 & 2683,6 & 2862,7 & 3058,3 & 3165,7 \\
\hline $\begin{array}{l}\text { В том числе: по областям } \\
\text { Белгородская }\end{array}$ & 1320,7 & 1503,2 & 1531,4 & 1618,7 & 1634,3 \\
\hline Воронежская & 330,1 & 372,2 & 321,4 & 342,9 & 382,4 \\
\hline Курская & 164,0 & 285,5 & 388,3 & 437,0 & 468,2 \\
\hline Липецкая & 220,1 & 259,2 & 280,0 & 312,4 & 318,5 \\
\hline Тамбовская & 204,4 & 263,5 & 341,6 & 347,3 & 362,3 \\
\hline
\end{tabular}


и предложены два сценария развития мясного животноводства ЦЧР. Первый вариант предполагает увеличение производства мяса всех видов в размерах, обозначенных в рамках прогноза социально-экономического развития страны [6]. Второй вариант позволяет учесть особенности функционирования мясного подкомплекса региона. Увеличение производства мяса будет в основном обеспечено за счет строительства новых и выхода на проектную мощность уже действующих свиноводческих и птицеводческих комплексов. Производство крупного рогатого скота на убой останется более инертной отраслью, что связано с большой длительностью производственного цикла и ростом затрат на производство. Необходимо отметить, что значительный вклад в развитие мясного скотоводства региона вносит Воронежская область, в которой реализуются инвестиционные проекты, предполагающие организацию племенного и товарного производства мясного скота [1]. Товаропроизводители Воронежской области в 2016 г. произвели 47,3 \% крупного рогатого скота на убой от общего объема в целом по региону.

К ключевым факторам, оказывающим влияние на прогнозируемые темпы роста развития мясного подкомплекса региона, можно отнести повышение спроса на мясо и мясопродукты за счет роста реальных доходов населения; а также реализацию экспортного потенциала.

Таким образом, в среднесрочной перспективе производство скота и птицы в живой массе хозяйствами всех категорий ЦЧР может достигнуть к 2020 г. 3864 тыс. т (табл. 2).

В настоящее время встает проблема не просто увеличения производства мяса, а предоставление потребителю продукции высокого качества в широком ассортименте. Следует отметить, что мясо и субпродукты, произведенные в регионе, стали пользоваться спросом за рубежом. Поскольку экспортные поставки требуют другого подхода к качеству продукции, то необходимо наряду с наращиванием производства развивать соответствующую инфраструктуру.

Таким образом, перспективы устойчивого развития мясного подкомплекса ЦЧР будут связаны с созданием высокотехнологичных комплексов по убою животных, инновационных предприятий глубокой переработки, логистических центров.

В этой связи представляет интерес исследование функционирования мясного кластера Белгородской области, поскольку она является лидером в ЦЧР по развитию мясного подкомплекса. Большая часть продукции (98,4 \%) приходится на сельскохозяйственные организации. В мясном балансе региона область занимает 51,6 \% [2]. В Белгородской области в птицеводстве и свиноводстве созданы вертикально интегрированные агрохолдинговые структуры замкнутого цикла, применяющие инновационные технологии, с производством продукции по принципу «от поля до прилавка»: от выращивания сельскохозяйственных культур, создания и загрузки комбикормовых мощностей, получения и переработки мяса до реализации полученной продукции через собственные торгово-логистические центры и утилизации отходов. Мощность производства мясного кластера области в 2016 г. составила 787,4 тыс. т свинины и 798,5 тыс. т мяса птицы в живой массе.

Показателен опыт работы крупного агрохолдинга «Мираторг», который является ведущим производителем и поставщиком мяса на российский рынок. В 2016 г. им было реализовано 409 тыс. т свинины, что составляет 26,6 \% от производства в целом по ЦЧР, 102,2 тыс. т мяса птицы (7,2 \%), 62,14 тыс. т говядины (31,2 \%) [5]. Компания постоянно внедряет достижения научно-технического прогресса, современные инновационные технологии. В Белгородской области запущен высокопроизводительный комплекс по переработке мяса «Casa-Ready» на СК «Короча», в котором широкое распространение получило применение роботов на самых сложных технологических процессах - убой и обескровливание животных, распиливание и разрез на полутуши. Уровень роботизации и глубокая переработка способствуют развитию безотходного производства, а также позволяют вырабатывать продукцию более высокого качества.

В целях обеспечения гарантированной пос-

Таблица 2

Прогнозные параметры производства скота и птицы на убой в живой массе хозяйствами всех категорий ЦЧР, тыс. т

\begin{tabular}{|c|c|c|c|c|}
\hline & & & & \\
\hline & \multirow{2}{*}{$\begin{array}{l}\text { В среднем за } \\
2012-2016 \text { гг. }\end{array}$} & \multirow{2}{*}{2016 г. } & \multicolumn{2}{|c|}{2020 г. } \\
\hline & & & I вариант & II вариант \\
\hline $\begin{array}{r}\text { Показатель } \\
\text { Скот и птица - всего }\end{array}$ & 2802,0 & 3165,7 & 3448,2 & 3864,0 \\
\hline $\begin{array}{l}\text { В том числе: } \\
\text { крупный рогатый скот }\end{array}$ & 200,7 & 199,0 & 199,4 & 199,4 \\
\hline свиньи & 1280,1 & 1536,3 & 1697,6 & 2090,1 \\
\hline овцы и козы & 13,5 & 14,3 & 14,3 & 14,3 \\
\hline птица & 1302,1 & 1411,4 & 1530,0 & 1552,4 \\
\hline
\end{tabular}


тавки производимой продукции в заранее установленные сроки «Мираторг» организовал собственную логистическую сеть, представленную различными дистрибьюторскими центрами.

Заключение. Современное состояние мясного подкомплекса ЦЧР характеризуется достаточно высоким уровнем развития. Активная государственная поддержка животноводства способствовала росту объемов производства скота и птицы на убой в живой массе за 20122016 гг. на 41,4\%.

В последние годы наблюдается увеличение доли сельскохозяйственных организаций в производстве мяса всех видов. Проведенные исследования позволили установить, что Белгородская область является одним из индустриально развитых регионов ЦЧР, поскольку большую часть продукции производят крупные интегрированные агрохолдинговые структуры с замкнутым циклом производства, использующие современные технологии на уровне мировых стандартов.

Предложенный прогнозный вариант с учетом региональных особенностей развития позволит увеличить производство мяса. При этом перспективные направления устойчивого развития мясного подкомплекса ЦЧР должны быть связаны с созданием высокотехнологичных комплексов по убою животных, инновационных предприятий по мясопереработке, логистических центров. Лучшего результата можно достичь также за счет более полного использования возможностей производства мяса хозяйствами населений, что требует дополнительных мер государственной поддержки.

\section{СПИСОК ЛИТЕРАТУРЫ}

1. Андрющенко С.А., Васильченко М.Я. Региональные условия и возможности развития молочно-мясного скотоводства в России // Аграрный научный журнал. - 2016. - № 6. - С. 73-81.

2. Белгородская область названа лидером по производству мяса в России. - Режим доступа: http://www. bel.ru/news/economy/09-02-2018/belgorodskayaoblast-nazvana-liderom-po-proizvodstvu-myasa-skotai-ptitsy.

3. Кучеренко О.И., Попкова Е.В. Состояние и тенденции развития свиноводства в ЦЧР // Вестник Воронежского государственного аграрного университета. - 2014. - № 1-2 (40-41). - С. 237-241.

4. Кучеренко О.И., Попкова Е.В. Состояние и тенденции развития мясного подкомплекса АПК ЦЧР // Вестник Воронежского государственного аграрного университета. - 2017. - № 1. - С. 182-187.

5. «Мираторг» - ведущий производитель и поставщик мяса на российском рынке. - Режим доступа: https://miratorg.ru/about/.

6. Прогноз социально-экономического развития Российской Федерации на 2018 год и на плановый период 2019 и 2020 годов. - Режим доступа: http://www. garant.ru/products/ipo/prime/doc/71700494/.

7. Производство продукции животноводства в Российской Федерации в 2013 г. - Режим доступа: http:// www.gks.ru/wps/wcm/connect/rosstat_main/rosstat/ $\mathrm{ru} /$ statistics/publications/catalog/doc $1 \overline{2} 65196018516$.

8. Производство продукции животноводства в Российской Федерации в 2014 г. - Режим доступа: http:// www.gks.ru/wps/wcm/connect/rosstat_main/rosstat/ $\mathrm{ru} /$ statistics/publications/catalog/doc_1265196018516.

9. Производство продукцииживотноводства в Российской Федерации в 2015 г. - Режим доступа: http:// www.gks.ru/wps/wcm/connect/rosstat main/rosstat/ $\mathrm{ru} /$ statistics/publications/catalog/doc_1265196018516.

10. Производство продукции животноводства в Российской Федерации в 2016 г. - Режим доступа: http://www.gks.ru/wps/wcm/connect/rosstat_main/rosstat/ru/statistics/publications/catalog/ doc_1265196018516.

Кучеренко Ольга Ивановна, канд. экон. наук, доцент кафедры «Организация производства и предпринимательской деятельности в АПК», Воронежский государственный аграрный университет имени императора Петра I. Россия.

Попкова Елена Викторовна, канд. экон. наук, доцент кафедры «Организациия производства и предпринимательской деятельности в АПК», Воронежский государственный аграрный университет имени императора Петра I. Россия.

394087, г. Воронеж, ул. Мичурина, д. 1.

Тел. 8 (473) 253-77-51.

Ключевые слова: мясной подкомплекс; ЦентральноЧерноземный регион; динамика производства мяса скота и птицы; перспективы развития.

\section{FORMATION AND DEVELOPMENT OF THE REGIONAL MEAT SUBCOMPLEX AT THE PRESENT STAGE}

Kucherenko Olga Ivanovna, Candidate of Economic Sciences, Associate Professor of the chair "Organization of Production and Entrepreneurial Business in Agro-Industrial Complex", Voronezh State Agrarian University named after Emperor Peter the Great. Russia.

Popkova Elena Viktorovna, Candidate of Economic Sciences, Associate Professor of the chair "Organization of Production and Entrepreneurial Business in Agro-Industrial Complex", Voronezh State Agrarian University named after Emperor Peter the Great. Russia.

Keywords: meat subcomplex; Central Black Earth Region; dynamics of cattle and poultry meat production; development prospects.
The analysis of the current condition of the meat production subcomplex in the Central Black Soil Region was carried out. The study reveals that at present there are positive changes in the meat production subcomplex of the region, which occur due to accelerated growth in pork and poultry meat production. It is concluded that over the period under review, there was an increase in production in agricultural organizations and a decrease in the households. The forecast parameters of the meat subcomplex in region were defined. The performed research made it possible to determine prospective directions for sustainable development of the meat subcomplex of the Central Black Soil Region, that include creation of high-tech slaughter complexes, innovative meat-processing enterprises, and logistics companies with wide network of distribution centers. 